\title{
Psychoanalytical Child Psychotherapy: The Parent's Role
}

\author{
Julia Montazzolli Silva \\ Universidade Estadual de Londrina, Londrina, PR, Brazil \\ Maria Elizabeth Barreto Tavares dos Reis ${ }^{1}$ \\ Departamento de Psicologia e Psicanálise da Universidade Estadual de Londrina, \\ Londrina, PR, Brazil
}

\begin{abstract}
The comprehension of the parents' relation with their child's psychotherapy has developed considerably since the beginning of child psychoanalysis, elevating the importance of active participation of family into the patient's treatment, as also the attention of the therapist to unconscious phenomena that occur in this context. This issue refers to a narrative revision of psychoanalytical literature about presence of parents in child psychotherapy, which objective refers to analyze the way contemporaneous authors who work with psychoanalytical perspective understand the parents' role in child psychotherapy. Initially, were consulted books of classic authors in psychoanalysis, and a specific book of more contemporaneous authors about the matter of the parents' role in child psychotherapy. Articles about the same theme were then searched into the scientific electronic basis SciELO (Scientific Electronic Library Online), PePsic (portal of Electronic Psychology Journals) and LILACS (Latin American and Caribbean Health Sciences Literature). Were selected for analysis 19 articles published at online papers. It was verified that the texts approached specially the position of analyst/psychotherapist and the relations established with the patient's parents, being emphasized, mainly, the necessity of receiving the parents' anguishes and their transference directed to the therapist, creating an space of continence, reflection and ressignificance of the child's problem.
\end{abstract}

Keywords: Parental role, psychoanalysis, child psychotherapy.

\section{Psicoterapia Psicanalítica Infantil: O Lugar dos Pais}

\section{Resumo}

A compreensão da relação dos pais com a psicoterapia do filho desenvolveu-se consideravelmente desde o início da psicanálise com crianças, elevando a importância da participação ativa da família no tratamento, bem como da atenção do analista ou terapeuta diante de suas manifestações inconscientes que se fazem presentes nesse contexto. $O$ presente trabalho consiste numa revisão narrativa da literatura psicanalítica sobre a presença dos pais na psicoterapia infantil, tendo como objetivo analisar a maneira pela qual autores que trabalham com a perspectiva psicanalítica na atualidade compreendem a participação dos pais no tratamento. Foram consultados inicialmente livros de autores considerados clássicos na psicanálise e um livro específico sobre o lugar dos pais na psicanálise de crianças de autores mais

Mailing address: Av. Gil de Abreu e Souza 2335, casa 227, Londrina, PR, Brazil 86058-100. Phone: (43)99949872. E-mail: bethtavaresreis@gmail.com

O artigo foi elaborado como trabalho de conclusão do curso de especialização em Clínica Psicanalítica, na Universidade Estadual de Londrina, pela primeira autora com orientação da segunda autora. 
contemporâneos. Em seguida foi realizada uma busca nas bases de dados eletrônicas SciELO (Scientific Electronic Library Online), PePsic (portal de Periódicos Eletrônicos de Psicologia) e LILACS (Literatura Latino-Americana em Ciências da Saúde), a respeito do assunto. Foram selecionados para a análise 19 artigos publicados em periódicos on line. Verificou-se que os textos abordaram especialmente a postura analista/psicoterapeuta e as relações estabelecidas com os pais da criança atendida, sendo enfatizada, principalmente, a necessidade de acolhimento das angústias parentais e da transferência dirigida ao analista, proporcionando aos pais um espaço de continência, reflexão e possibilidades de ressignificação da problemática da criança.

Palavras-chave: Papel dos pais, psicanálise, psicoterapia infantil.

\section{Psicoterapia Psicoanalítica Infantil: El Rol de los Padres}

\section{Resumen}

La comprensión de la relación de los padres con la psicoterapia del hijo se desarrolló considerablemente desde el comenzo del psicoanálisis de niños, elevando la importancia de la participación activa de la familia en el tratamiento, así como de la atención del analista o terapeuta delante de las manifestaciones inconscientes de ella que se hacen presentes en esto contexto. Lo presente trabajo corresponde a una revisión narrativa de la literatura psicoanalítica sobre la presencia de los padres en la psicoterapia de niños, teniendo como objetivo analizar la manera pela cual autores que trabajan con la perspectiva del psicoanálisis en la actualidad comprenden la participación de los padres en la psicoterapia de los niños. Fueron consultados, inicialmente, libros conteniendo de autores considerados clásicos en el psicoanálisis y un libro de autores más contemporáneos sobre el mismo tema. Después, se realizó una búsqueda en las bases de datos electrónicas SciELO (Scientific Electronic Library Online), PePsic (portal de Periódicos Eletrônicos de Psicologia) y LILACS (Literatura Latino-Americana em Ciências da Saúde), sobre el tema. Fueron seleccionados para análisis 19 artículos publicados en periódicos electrónicos. Se ha verificado que los textos abordaban especialmente la postura del analista/psicoterapeuta y las relaciones establecidas con los padres del pequeño paciente, teniendo sido enfatizada, sobretodo, la necesidad de una acogida de las angustias de los padres y de la transferencia dirigida al analista, proporcionando a estos un espacio de continencia, reflexión y posibilidad de resignificación de los problemas presentados por el niño.

Palabras clave: Rol de los padres, psicoanálisis, psicoterapia de niños.

Since psychoanalysis started to be carried out with children, the participation of the parents and the way they position themselves faced with the treatment of their children, consciously and unconsciously (Priszkulnik, 1995), as well as their comprehension of the objectives, scope and limits of the treatment, have been shown to be of particular importance in the therapeutic process as a whole. In the present study, the psychoanalytic psychotherapy of children also refers to interventions of a psychotherapeutic nature based on the psychodynamic theories, which do not necessarily correspond to a model of traditional psychoanalysis, where sessions occur more frequently and the aims of the treatment refer to a restructuring of the personality, from the use of the interpretation and deep analysis of the transfer phenomena and other displacements (Sours, 1996). The referenced authors, whose works were selected for analysis, use distinct terms to delimit their object of study, sometimes referring to childhood psychoanalysis and sometimes psychoanalytic psychotherapy. It was decided to maintain the terms originally used when citing the ideas of the authors. 
Although the patient brought to the intervention is the child, the inseparability of his psychic world and that of the parents, with the total dependence of the child for the payment of fees and transportation to the place of the service causing the relationship of the parents with the child, and even the individual issues of the parents, to be constantly present in the childhood psychoanalytical psychotherapy. The adherence to the therapy and its effectiveness are often identified as entirely dependent on the paternal psychic functioning, with the psychotherapy of the child often being interrupted early due to the unilateral decision of the family, a decision about which sometimes there is no knowledge of the real motivation and underlying issues that caused it.

Thus, the study of the relationship that exists between the parents and the psychotherapy of the child can be considered important to comprehend the reasons that lead to this phenomenon, so that, from it, ways to manage the issues involved can be generated. In order to contribute to these reflections, this paper aims to analyze the way in which authors working with the psychoanalytic perspective today include the participation of the parents in the psychotherapy of the child.

\section{Psychotherapy in Childhood}

It is estimated that 10 to $20 \%$ of Brazilian children suffer from psychiatric problems, with only a few receiving specialized care (Gastaud, Basso, Soares, Eizirik, \& Nunes, 2011). Deakin and Nunes (2009), and Nunes, Silvares, Marturano, and Oliveira (2009) have discussed the importance of conducting psychotherapy in childhood with children who require such services, preventing later development of mental disorders or worsening of the symptoms. The effectiveness of the treatment, however, will depend entirely on the child remaining in treatment until such time that there is the achievement of its objectives, with the mutual consent of the family and the therapist. The premature termination of psychotherapy is a disadvantage for the child and his family, as well as for the therapist and the institution where the psychology service is allocated (Nunes et al., 2009).

Psychoanalysis can be comprehended as a method of investigation into the unconscious processes and the subjective world and as a body of knowledge that consists of the constant questioning of the knowledge of the consciousness. It can also be understood as research, when dealing with the investigation of the psychoanalytic theory, derived from experience of analysts with the application of the psychoanalytic method (Nogueira, 2004).

Psychoanalysis of children, specifically, is seen as a privileged locus of discovery and of the emergence of difficulties in normalizing paradigms within the scientific field in which it is included (Bleichmar, 1994). According to that highlighted by Rosemberg (1994), from the works of Freud, the authors make their own readings of the method and psychoanalytic theory, which gave rise to the development of the question of the relationship of the parents with the analysis of the children from different perspectives, greatly affecting the clinical management.

\section{Method}

A historical review was conducted regarding the relationship of the parents with the analysis of the child during the evolution of child psychoanalysis, culminating with the performance of a literature review in electronic databases, aiming to identify resonances of the framework and/or changes in the current literature.

The first step of this study consisted of consulting the texts of some of the pioneering authors in the psychoanalysis of children, seeking to understand the historical development of the parental role in the psychoanalytic treatment of children and its management by these psychoanalysts. Among these works are the texts of Aberastury (1982a, 1982b), Ferro (1995), Freud (1909/1996), Klein (1997), Mannoni (1987) and Winnicott (1961/1980, 1962/1990) and the book organized by Rosemberg (1994), entitled "The Place of the Parents in the Psychoanalysis of Children". 
Next, a survey of articles indexed in scientific journals was conducted, in the LILACS (Latin American and Caribbean Health Sciences Literature), PePSIC (portal of Electronic Psychology Journals) and SciELO (Scientific Electronic Library Online) databases, given their greater coverage and the possibility of access to the material available on them. Using the respective search tools in each database, articles were sought with the following combinations of descriptors that could be contained in the titles, abstracts or keywords: psychoanalysis (in the subject field) + parents; place + parents + psychoanalysis; psychoanalysis (in the subject field) + childhood + parents; psychotherapy (in the subject field) + child + parents; psychotherapy (in the subject field) + childhood + parents. It should be noted that there is considerable similarity between these combinations, a fact that caused few differences among the results obtained with each one: many of the items considered relevant were repeated in the search in each database, although it was still possible to access some different texts.

The inclusion criteria of the texts found for the analysis proposed was that the material addressed the participation and role of parents in the psychotherapy of children from the perspective of psychoanalysis. The decision was also taken to work only with texts that were available online. The use of online databases for the storage of scientific publications is relatively recent, therefore, it was chosen not to restrict the period considered for publication of articles selected for the analysis.

The relationship between the members of the family and their vicissitudes, which influence the constitution process of the subject and his problems, figure as a central issue in psychoanalysis, so that many articles found dealt with these issues, without mentioning, however, child psychotherapy and the issue of the relationship of the parents with the treatment. These, as well those that dealt with issues, such as other forms of psychotherapy, parent-child joint intervention, parent-child psychotherapy and group psychotherapy were not selected for the analysis, considering that these interventions have their specificities, which deserve to be studied more carefully, in works with different objectives to those of the present study.

\section{Results and Discussion}

Despite the considerable list of items suggested by the LILACS database, adding the titles obtained with all the combinations of words, it was found that 8 articles relevant to the theme were not available online in this database at the time of the search. Furthermore, given the proximity between the combinations of descriptors, the search resulted in repetition of the same texts in different databases. The articles selected for the present study are presented in Table 1 .

Finally 18 works relating to the question of the participation of parents in the psychoanalysis of children were selected for reading and analysis. The works of the authors Andrade et al. (2012), Klinger et al. (2011), Oliveira (2002), Sei et al. (2008), Serralha (2009), dealt with childhood psychotherapy with a psychoanalytic orientation, the authors Ferrari (2012) and Soler and Bernardino (2012) mention both psychoanalysis and psychotherapy of children and the other authors mentioned in the table dealt with the performance of psychoanalysis of children.

It was found that, even though the search for works using terms that referred to parenting and psychoanalysis produced a large number of articles, this number was greatly reduced when the searches were associated with the theme of child psychotherapy, so that the comprehension and management of the parental relationship in child psychotherapy does not seem to have been the focus of many studies. The indexed articles chosen for analysis were published during the period between 2000 and 2014, with the exception of one, which was published in 1995, indicating both a more recent interest in the subject as well as the choice of taking only texts available in digital format as the research object. Parallel to that found, Cabral and Levandowski (2011) pointed out that, despite having special importance in psychoanalysis, the influence of the maternal representations on child development only started to be examined closer by psychiatry from the 1970 s, supporting 
Table 1

Articles Selected for Analysis

\begin{tabular}{|c|c|}
\hline Authors & Title \\
\hline $\begin{array}{l}\text { Andrade, Mishima-Gomes, } \\
\quad \text { \& Barbieri (2012) }\end{array}$ & $\begin{array}{l}\text { Vínculos familiares e atendimento psicológico: A escuta dos pais sobre } \\
\text { a alta da criança }\end{array}$ \\
\hline Checchinato (2002) & Psicanálise dos pais \\
\hline Ferrari (2012) & Sintoma da criança, atualização do processo constitutivo parental? \\
\hline Klinger, Reis, \& Souza (2011) & A inclusão dos pais na clínica das psicoses infantis. \\
\hline Leone \& Mariotto (2007) & Controvérsias no tratamento psicanalitico com crianças: Qual o lugar dos pais? \\
\hline Lerner (2002) & A dimensão da enunciação no discurso da mãe acerca da criança psicótica \\
\hline Lisondo (2001) & $\begin{array}{c}\text { O lugar dos pais na análise de crianças e adolescentes: Uma menina-rainha } \\
\text { em um trono-trincheira-prisão mental }\end{array}$ \\
\hline Martinez (2014) & $\begin{array}{c}\text { Ressonâncias do inconsciente materno e familiar na sintomatologia infantil } \\
\text { e no setting analítico à luz de um caso clínico }\end{array}$ \\
\hline Melo, Andrade, \& Lima (2012) & Superando o falicismo: Sofrimento materno na psicanálise de crianças \\
\hline Oliveira (2002) & Critérios de indicação para psicoterapia breve de crianças e pais \\
\hline Petriciani (2011) & Uma relação tão delicada \\
\hline Priszkulnik (1995) & A criança e a psicanálise: $O$ "lugar" dos pais no atendimento infantil. \\
\hline $\begin{array}{l}\text { Quagliatto, Cunha, Chaves, } \\
\text { Pajola, \& Lemgruber (2008) }\end{array}$ & $\begin{array}{c}\text { Evoluções e revoluções na clínica psicanalítica infantil: Da orientação } \\
\text { aos pais à avaliação-intervenção conjunta pais-filhos }\end{array}$ \\
\hline Sei, Souza, \& Arruda (2008) & $\begin{array}{l}\text { O sintoma da criança e a dinâmica familiar: Orientação de pais } \\
\text { na psicoterapia infantil }\end{array}$ \\
\hline Serralha (2009) & Winnicott com Gabrielle e seus pais \\
\hline Soler \& Bernardino (2012) & A prática psicanalítica de Françoise Dolto a partir de seus casos clínicos \\
\hline Souza (2012) & $\begin{array}{c}\text { Existe um lugar para os pais reais: Reflexões sobre o lugar dos pais } \\
\text { e do analista real na psicanálise de orientação kleiniana }\end{array}$ \\
\hline Whitaker (2003) & O sintoma da criança como efeito do gozo materno: Entrevistas preliminares \\
\hline
\end{tabular}

the hypothesis that interest in the topic has been growing in recent decades.

\section{The Development of Child}

Psychoanalysis and the Evolution of the Place Given to the Parents in the Therapeutic Process

Through the analysis of the texts it was perceived that listening to the parents has gradually became a subject of interest and the place given to the parents in the psychoanalysis of the child has also evolved considerably since its inception. The way in which this listening is used and managed, however, has been addressed in various ways, according to the psychoanalytic line taken as the basis for the child psychotherapy in question.

Commenting on the analysis of little Hans by Freud, performed almost exclusively through contact with the father of the child, Mannoni (1987) points out that the sick child presented himself as ". . . support for what the parents cannot face - the sexual problem" (p. 15), shown to be present in the relationship of the parents of Hans, compromising their marital relationship. The author, based on the theoretical framework of Lacan and from her work extensively developed with psychotic children and their families, 
points out that, in the case described by Freud, it is possible to show the inevitable involvement of the parents in the symptom of the child, in that the network of the anguish was primarily located in them, from which the symptom was formed. However, due to the lack of knowledge regarding the experience with immature children, Freud did not explore these issues when dealing primarily only with those parents of the reality, even trusting the treatment of the boy to them. The interpretation of Mannoni (1987) regarding the phobia presented by Hans, connecting the symptomatology of the child to the unconscious issues of his parents, underlies that proposed by Rosemberg (1994), who states that the maternal unconscious imprints itself on the child in the structuring of his own imagination. It is noteworthy that despite this assertion, for Mannoni, it is the child who will structure his own psychic world (Rosemberg, 1994), in a way that there are moments in which the subjectivities intersect, and the interference of the mother has an active role in the healing process of the child, whose psyche under construction is strongly tied to the parental phantasmal.

Mannoni (1987) considered the introduction of the parents essential in the healing process of the child, however, had reservations about the proposal to attribute an educational attitude to them, ". . . intervening in the plane of reality, in the issues concerning family life" (p. 58), giving the therapy the perspective of a corrective experience, in which the analyst will guide the parents about what to do, leaving the place of the analytic relationship, to occupy another, more educational space.

Prior to the development of the work and perspectives of Mannoni, and in a quite different theoretical framework, Klein (1997) also emphasized being contrary to a pedagogical positioning. Regarding the attitude toward the parents, compared to that proposed by Mannoni (1987) and Klein (1997) situated herself, however, in favor of maintaining contact with the parents who would restrict themselves to the essential minimum. For Klein (1997), contact with the parents should not exceed the explanation of the meanings and effects of the analysis, as well as interventions of a more active nature only being used when the child was in real risk, that is, when gross mistakes had been made within the child's environment. The primacy of this position was justified for the author because it presupposes an ambivalent and delicate relationship of the parents in relation to the psychoanalysis of the child, with who the ideal would be to maintain a relationship of cooperation and trust. Its support in the success of the treatment lay much more in the child's ability to enter into an analytical process and to benefit from it, than in the subjective involvement of parents in this process. For her, if the development of the analysis depends on the information provided by the parents, due to heavy and long periods of resistance, something wrong may be occurring with the treatment, compromising its effectiveness and the confidential relationship with the patient. Aberastury (1982a), from his clinical practice, position himself in agreement with Klein, and emphasize a refusal to advise the parents or make any suggestion in their behavior with the children. The effectiveness of these interventions, for the author, was difficult to sustain in the family environment of the child and ended up generating in the parents a guilty feeling that turned into aggression and distrust, difficult to manifest in the moment of the interview with the analyst, thus leading to the interruption or impairment of the treatment in other ways.

Discussions about the place of the parents in the analysis of the children, therefore, accompanied the development of the theory and the creation of different practices, according to the psychoanalytic line with which the psychoanalysts work (Camarotti, 2010). As can be perceived from the above statements, the posterior development of the psychoanalytic psychotherapy of children seems to have led to the development of the concept of possible ways to manage the relationship with the parents of the child, without compromising the therapeutic process and the relationship with the patient. According to Mannoni (1987), by adopting a distance from the parents in the treatment, the dimension of the place of the maternal word in the fantasy world of the child 
is lost, the symptom of which is the expression of its permanence. The author believes that, in the case of concurrent and separate analyzes of the parents and of the child, the analyst loses important work material, having access only to the manifest attitude of the mother, and not to her discourse. Thus, according to that highlighted by Rosemberg (1994), when the unconscious of the parents maintains a direct relationship with the symptom of the child or his neurosis, a change is also needed to the level of this parental unconscious, so that the process of therapy can be successful (Rosemberg, 1994). For the author there would be no possibility of working with the child without, in some way, including the parents. On the other hand, Bleichmar (1994) notes that there is no use in the assumption that the work with the parents will simply reach the symptom of the child, resolving it. If there is a relationship between the symptom of the child and the discourse of the parents, it is still necessary to work with the consequences and conditions of this fact, since it is not possible to act on the determinants, as they figure in the past. It would be necessary therefore both to welcome and give a destination to the implicit demand presented by the child himself, as well as to open space for the involvement of the parents, which would be, for her ". . . essential for the therapeutic process to find the pathways of realization that consolidate that which is inaugurated in the clinic" (Bleichmar, 1994, p. 153).

Furthermore, it should be noted that there is a gap between the demands made of the therapist by the parents and by the child. Looking at the psychic functioning of the family, an imprecision can be perceived in the limits between what belongs to the parental phantasmagoric and what belongs to that of the child, the action of the superego and the egoic function of each one, as shown by Rosemberg (1994). The author argues that there is thus a overlap of the psychic dynamics of the parents and of the child in the formation of his subjectivity, bringing complexity to the location of this desire and to the comprehension of the etiology of the symptom. The difficulty in specifying the place of the parents in the therapy of the child is again evident, given that the parental phantasmagoric and the psychic world of the child are always intertwined, a fact that the analyst will encounter constantly.

Rosemberg (1994) also points out that the preservation of the treatment and the adoption of an appropriate position to consider the place of the parents assumes that the child remains the focus, with whom the analytical work will be performed, which does not prevent, however, the discourse of the parents and other figures, who help the patient to ". . . find lost pathways" (p. 49), from being present. For example, it may be that such discourses allow the little patient to extricate himself from the experience of paralyzation in the analytical process, corresponding to moments in which pieces of his history as the subject of desire remain tied to the discourse of one of the parents. The work is, therefore, with the parents of the reality

... not because it is not possible to work with the symbolic parents or phantasm, but because their discourse allows the child to find remains taken from the imaginary of his parents to assemble, in turn, his own imaginary. (Rosemberg, 1994, p. 52)

According to Mannoni (1987), regardless of having her own analysis space, the mother makes herself heard in the treatment process of the child, whose symptom is the expression of her anguish - the child occupies a certain place in the phantasm of the parents, and cannot be artificially isolated from this context. Accordingly, Rosemberg (1994) states that there are moments in which what appears in the treatment are the problems related to the Oedipus and the castration of the parents, who are restructured in the child himself. He also repeats and resists, and the parents end up interrupting the therapeutic process.

To welcome the suffering of the parents is part of enabling the child to become the subject of the treatment and go in search of his own desire - a movement would also be the goal of the psychotherapist whose work is based on the theory of psychoanalysis. This movement is solidified from the moment in which, thanks to the 
relationship of the parents with the analyst, the mother allows this.

\section{Psychoanalytic Psychotherapy of Children Today and the Management of the Presence of the Parents in the Therapeutic Setting}

The literature found in the electronic databases of this study does not contradict the points made above, on the contrary. It adds, however, several issues, constructed from the clinical practice with children _ it should be noted that almost half of the articles included vignettes of situations experienced in working with children and, in one way or another, their parents.

One of the particularities of the psychoanalytic guidance therapy of the child refers to the origin of the requirement for analysis/treatment. Whereas, with adult patients, the initial path to the analysis is the desire of the patient, in the psychoanalysis of children, this desire is rarely expressed, originating from a demand in general of the parents (Soler \& Bernardino, 2012), of the family or of other bodies with whom contact is maintained, such as the school and the pediatrician (Leone \& Mariotto, 2007; Whitaker, 2003).

Added to this is the fact that when parents seek psychotherapeutic help for the child, they already have a burden of suffering, in which they feel guilt and embarrassment (Petriciani, 2011). According to that highlighted by Lisondo (2001), the psychoanalysis of children and adolescents will inevitably lead to changes in the family bonds - the arrival of the parents at the clinic already indicates the disorganization of the psychic homeostasis of the family. For the author "... The child illuminates and denounces, with the various forms of psychic disturbance, the psychic disturbances suffered in the parents" (p. 97). The anguish, faced with this realization, grows as the interviews with the analyst develop and the parents perceive traces of their issues in the symptomatology of the child (Andrade et al., 2012; Klinger et al., 2011). The collocations of Whitaker (2003) also corroborate the presence of parental discomfort given this contact, and highlight the need for the psychotherapist to seek to create a workspace where the anxiety is tolerable, so that the parents can be involved with what for them is manifested in the symptom of the child - a factor on which the improvement of the child greatly depends. Ferrari (2012), addressing the fact that the idealization of the child by the parents refers to the desire to return to a state of narcissistic completeness, says that the symptom appears as the element that triggers the experience of the castration by the parents, in the case, in a double identification, both with their own parents, as well as with themselves as children, unable to satisfy the parental desire.

Despite prior assumptions by the therapist, there are movements of the parents faced with the mobilization of these different feelings in the search for treatment for the child, that are often completely unconscious, permeated by defenses and other issues that conceal the parental involvement in the symptoms of the child. Accordingly, Gastaud et al. (2011), in a study about the abandonment of child psychotherapy, concluded that there is a statistically greater chance of therapy abandonment in cases where the parents present ambivalent motivation or unrealistic expectations about the therapy. From this perspective, what is required of the therapist is often to suppress undesirable behavior, a fact that is frequently incongruous with the desire of the child (Leone \& Mariotto, 2007), whose symptom is the result of a chain that sustains him as the subject. Winnicott (1961/1980), faced with the indication of psychotherapy for a child, considered not only the diagnosis and the availability of the psychotherapist, but also how much the family would be able to accept and assume the illness of the child, supporting him until the treatment actually began to take effect. For the author, the greater the emotional compromise of the child, the greater the emphasis on the need to have a co-therapeutic environment (Winnicott, 1962/1990), which would only be possible with the adequate management of the relationship with the family. Oliveira (2002) agrees with this, especially when considering short treatments, in that their effectiveness greatly depends on the possibility that the environment in which he is inserted accepts and welcomes the changes that can take place. Aberastury (1982a) also point- 
ed out the importance of assessing the family's ability to comply with the treatment, not only in terms of psychic functioning but especially in terms of the considerable investment of time and financial resources that an analysis requires. Accepting the anxieties of the parents at the time of the consultation and, depending on family relationships and the understanding of information about child development, proposing ways to deal with some of the child's behavior would be, for the author, more relevant than proposing psychoanalytic treatment to a family that could not make it available to the child.

However, it should also be considered that sometimes an evaluation of the symptom reported by the parents is required, as the dimension does not always constitute the problem reported. For example, there are cases where the expectations of the parents regarding the child are beyond what his cognitive, motor and emotional capacity and stage of development would be, with it being necessary, in this case, to work with this expectation and with the parental ideals placed on the child. In this sense, it is necessary to listen attentively to the demands made by the child and parents, aiming to differentiate them, showing the symptom "in" and "of" the child (Leone \& Mariotto, 2007). When the demand originates in the social environment and in the family, being shown as a symptom "in" the child, it is necessary to work with the desire of the parents in relation to the child and to the cultural requirements that are expected of the child. In such cases, the request of the parents contains, in addition to a concern for the child's suffering, the dissatisfaction and the request for the aforementioned narcissistic restoration, a difficulty of the parents to accept the real child who is different to how they idealized him (Petriciani, 2011). Andrade et al. (2012), on the other hand, cite the fact that there is a recurrent demand on parents to offer the child extra care, something more, that they feel they should be able to offer, however, cannot, in an effort to avoid or expel certain guilt. It should be noted at this point, particularly, the importance of the diagnostic hypothesis in the guidance of the work of the psychologist in each case and in the adoption of a posture by includ- ing the parents in the therapeutic process of the child (Leone \& Mariotto, 2007; Lisondo, 2001).

To confer a key role upon the parents, without losing the dimension that the central issue is the symptom of the child, also means considering the discourse that takes place in all of the psychotherapy with the inclusion of the parents, child and analyst around the symptom of the child (Petriciani, 2011; Priszkulnik, 1995). The mother-child or parent-child dyad does not always contain the possibility of including a third member, a fact that the therapist should manage with care (Priszkulnik, 1995).

For Whitaker (2003), although an analytical listening to what the parents have to say is performed, they do not put the therapist/analyst in the place of supposed knowledge, not immediately authorizing him to speak about their relationship with the child. The position of the analyst is posed by these parents, at first, as the one who testifies to the perception of an abnormal child whose behavior needs to change. The analytical relationship between the parents and therapist will be established to the extent to which it offers a place of listening and comprehension of the position of the mother and, at the same time, the questioning of her certainties about the child. Inadequate management of the emotions raised by this process, however, can lead to discontinuation of the treatment (Whitaker, 2003).

It also happens that, on various occasions, the active search of the parents for the analyst during the course of the treatment, to talk to him about the child, figures as a masked enunciation of a problem that belongs to the mother/couple/ parents (Melo et al., 2012; Priszkulnik, 1995). For Priszkulnik (1995), analytical listening allows the parents to be helped ". . . to re-dimension the problems of the child and to re-situate themselves in relation to their own problems" (p. 98). Not responding to the pedagogic demands of the parents and maintaining the offer of a listening that allows the truth to be revealed, it is possible to help them formulate the question no longer from the child, but from their own anguish felt when faced with this revelation.

Conversely, although criticism is directed toward the Kleinian stance regarding not having 
contact with the parents, as far as possible, Souza (2012) points out that the concept of projective identification, so important in the theory and psychoanalytic method of Klein, sheds light on an effective way to conduct the work with them and to understand them in their involvement with the symptom of the child. According to the author, projective identification presupposes the interrelationship between people, in which the content projected by one of the parts in fact affects the other. To bring to the consciousness those processes that would be in the genesis of many of the problems presented by the child, is highlighted by him as a way to provide a therapeutic effect to the work with the parents of the reality, making the reframing of conflicts feasible and the expression of these in other ways that generate less suffering.

Based on the Lacanian theory, Checchinato (2002) points out that the situation becomes more complicated when the problem of the child is more related to the subjectivity of the mother: when the child responds only to the lack, covering it up and alienating the mother from the contact with the truth. Thus, the importance of her role is highlighted - the first person to start directing the child to the world of language - and that of the family, responsible for the organization of the main processes of psychic development, for the transmission of content that exceed the limit of consciousness. It is also the mother who will assist the child in directing the drives. Without this direction, and without submission to the law, without being able to give an outline to the psyche, the child goes crazy, and that which cannot be symbolized appears in the outside world in the form of delusion. According to Klinger et al. (2011), listening to the parents allows the comprehension of the place the child occupies in their desire, making it possible to grasp the performance of the functions of insertion of the child in the language and in the realm of desire and to disrupt the maternal alienation.

The reading that Checchinato (2002) makes of the psychoanalytic theory about this subject, especially based on Lacan and Mannoni, rests on the comprehension that the concept of men- tal disease involves the question of the Oedipus complex, a process that has structural value for the human psyche. Given this concept, the author interprets that the plot in which the child is involved with the parents is too imperative and closed to be interrupted only working with the child. It is necessary to work with the parents and to support them in their ability to become aware of their issues, which heavily influence the symptom of the child, rejecting the forms of enjoyment that promote the current organization of the family.

The socio-cultural changes that accompanied the development of psychoanalysis include new demands brought by the family to the child therapist, whose attitude of openness to listening to the family anguish became indispensable, enabling obstacles in the child's healing process to be resolved (Martinez, 2014). In addition, various forms of care for parents and children were created to meet different demands that were presented to the clinic, seeking to diagnose the problems brought up by the family and therapeutic actions in moments of contact with the parents, such as in the therapeutic consultations and joint parents-children therapy and the orientation of parents within the framework of psychoanalysis. This modality is described as feasible over a delimited period and when aimed at resolving a particular issue (Quagliatto et al., 2008; Sei et al., 2008).

The transference of the parents in relation to the analyst of the child seems to be a factor of particular importance. According to the assertion of Oliveira (2002), the pre-transference of the parents seems to maintain a direct relationship with the type of projection directed at the child, which will probably manifest itself in the same direction with respect to the analyst. As a result, for the author, a pre-transference of a, predominantly positive, neurotic character would be essential to obtain good results with brief psychotherapy, for example. Furthermore, the presence of the parents as a certain invasion of the treatment of the child is carried out in various ways, often in the form of a boycott of the analysis, or in the attack on the place of the analyst, as well as through demands of positioning 
regarding the external issues, such as education and justice, the formation of confusion and secrets with the child or, as very often happens, withdrawal from the treatment (Lisondo 2001; Melo et al., 2012). It is therefore necessary, to consider, in a general way, the influence of the transference of the parents onto the analyst, which will take place in a special way, even if they are not included in the treatment (Lisondo, 2001). It seems unanimous that it would be preferable if it occurs within the setting, so it can be managed. The transference originating from the parents to the therapist, according to Petriciani (2011), should be fully accepted by him, whom she suggests maintains a state of mental receptivity, trying to accommodate what is primitive and unthinkable in the content brought by the parents, so it can be returned to them in a thinkable way. These findings, as pointed out by the same author and also by Lisondo (2001), focus on the issue that it does not mean to seek a restitution in the treatment, according to the demand of the parents, but to open space for reflection and psychic work, providing the amplitude of the consciousness and the perception. In the same perspective, anxieties of the parents that are not metabolized, nameless terrors, are for Martinez (2014), as well as for Souza (2012), the contents of which the therapist should be occupied, which often end up overwhelming the care of the child with their emotional intensity.

According to Soler and Bernardino (2012), the fact that often the treatment is especially anxiogenic for the parents, with the improvements of the child distressing and frightening them, also affects the child himself in his relationship with the psychotherapy. According to the authors, this, in turn, captures the reaction of the parents to his treatment and improvement, generating resistance to an analysis, that turns out to constitute a particularly painful process for both parties. In summary, the analyst must create the conditions so that parents allow the treatment process of the child, a challenge that includes defending the delimitation of the therapeutic setting firmly, but not mandatorily - a delicate positioning, as corroborated and highlighted by Petriciani (2011).
Leone and Mariotto (2007), considering the dialectic in which the analyst is involved with his little patient and parents in the treatment, postulate that he should occupy the place of no demand - letting the patient's own desire emerge, welcoming and supporting the different demands of the patient and his parents. Sei et al. (2008) highlight the need to observe and evaluate the feelings and demands of the family exposed to the therapist, as well as their ability to understand and care for the child in treatment, so that they can de directed toward modalities of care that will culminate in the greatest benefit for both parties. They mention, thus, the importance and possibility of positive results in the orientation of parents, not as the provision of advice, but as a possible way to assist them in the comprehension of the issues and process of development of the child. This assertion is supported by Aberastury (1982a), whose work with the guidance of mothers led her to verify the prophylactic value of such interventions in relation to future disorders of the patient. When the professional's position is that of a psychoanalyst of the child, however, the author states that he must take charge of this treatment and delimit his role and commitment to the child's symptom, so as to avoid that parents feeling judged and so alleviate some of their distress (Aberastury, 1982b).

There are cases, however, where the family presents to the therapist anxieties and feelings that are directed toward other issues that sometimes require the space of an individual therapy, sometimes require receiving the family together in a single care space, or through a integrated network of care that articulates the different demands that are presented and enable changes in the family as a whole, without which the therapy with the child cannot achieve success (Sei et al., 2008).

The choices on the best way to provide this analytic listening to the suffering of the family group composed by the patient and his parents, says Martinez (2014), only works if they are made as the treatment takes its course and the therapist comes into contact with what is happening. For Oliveira (2002) a greater dependence of the child in relation to his parents, 
high expectations directed toward the child, little sense of being involved in the problem and low tolerance for change are examples of factors that require more extensive and intensive work with the parents (Oliveira, 2002).

On the other hand, according to Checchinato (2002), analysis of the parents should be the principal focus of attention of the analyst. The place of the child, from his perspective, is always a symptomatic place, so that the child materializes projections of ideals, frustrations and problems of the parents into symptom, and it is in this condition that the child would be, for this author, considered in the analysis of the parents. In this care mode, there would be little or no contact with the child. Strongly focusing on truly psychoanalytical listening of these parents, providing them with a meeting with the unconscious and the truth of their own desires, the author attests that the effects on the child's symptoms are evident: "The symptom (of the child!) hides a truth: the truth of the couple" (Checchinato, p. 46). The author contraindicated the practice of analysis of the parents in obtaining resolutions for the symptom of the child in situations where he presents severe psychosis or a limitation of physical/biological origin and in cases where there are school delays requiring psychopedagogic work. The author also highlights that the analysis of the parents should be attempted in other cases, unless dealing with perverse parents or those with very low intellectual capacity.

The work of the author, therefore, was the only one covered in this study that emphasized working separately with the parents. However, even Mannoni (1987), cited by Checchinato (2002), observed that the analyst can run the risk of losing material and important intervention possibilities for the mother and the child when the analysis is carried out exclusively with the parents. Ferrari (2012) points out that a possible mistake in the reading of Mannoni would be to understand his posture as giving priority to the issue of family dynamics, instead of referring to the subjectivity of the child, considering that his emphasis on working with the parents aims ". . . to comprehend the history of the parental lineage in order to establish the place that this child in particular occupies in this generational chain" (Ferrari, 2012, pp. 303-304).

Given the tendency for the demand of the parents to fundamentally differ from the demand of the child, as the patient, Petriciani (2011) points out that in his practice, he found it useful to tell the caregivers, in advance, that the child will probably present, in the course of the therapeutic process, a symptomatic improvement in the short term, which does not mean that the treatment is complete. On the contrary, the author seeks to explain to the parents

... that possibly the "symptom", a way in which the child shows his difficulties, may quickly disappear, however, that does not mean that the difficulties have been overcome: it only means that there is no need for a call for help and that, in a way, the child feels that he is being cared for. (p. 161)

Lisondo (2001) also highlights this reaction of the parents as a way to avoid a deeper contact with the psychic reality, describing it as an idealization of the real achievements of the treatment. Working with the parents may still have the function of assisting them in the process of grieving for the idealized child, to finally enable the connection with the real child. The psychotherapist can thus lend his comprehension of the psyche of the parents, drawing on the maternal function in the attitudes of anticipating and enabling the emergence of meaning, to make it possible to look, desire and feel the real child, needing to promote the strengthening of the links between him and his parents. The analyst also needs, in special cases, such as when the child is at risk, "to speak in the name of knowledge" (Paravidini \& Chaves, 2011, p. 8), guiding (and again paying attention here to the fact that this does not mean to take a merely pedagogical position) and providing a backup. Whitaker (2003) adds that the analyst should also act in a way to enable the exit of the parents from the position of holders of an absolute knowledge about the child, placing himself as an investigator and not attributing the truth to himself, thereby operating the paternal function.

The theme of the possibility of the family conceding to the child a place of the subject of 
desire was also highlighted by the other authors, especially with reference to psychoses and severe cases of mental illness in childhood. Although a particular parental type cannot be coupled to a single and decisive relationship with the diagnosis of the child, Lerner (2002) and also Melo et al. (2012) suggest that an attentive look at the transference manifestations of the parents in these cases allows a particular comprehension of their relationship with the etiology of the symptom and with the development of the therapeutic process. Also according to these authors, when the parents look at the child in a way that denotes certainties that are difficult to challenge, and in particular when there is nothing to suppose there (Lerner, 2002), there is not, consequently, a possible mother for an impossible child, this child that can only be in the condition of who never learns, will not have anything to say, will not evolve. These parents are in the place of impotence, as is the analyst, whose interventions can often be rejected, repulsed - demeaned. The maternal suffering thus denotes the phallic place of the child at the expense of a high price in terms of the anxiety and of the permanence of untranslated parental puzzles (Melo et al., 2012). It is a complex picture in which the health of the child will depend on the possibility of the posture of the mother changing, referring to a third instance that makes a cut in this relationship of unequivocal holder of certainties about the child. As in the statement of Ferrari (2012), "In the moments when the mother places herself as not all-knowing about her baby, she calls up, even if indirectly, the paternal metaphor which will enable the exit of the baby from this alienation" (p. 309).

Leone and Marioto (2007) confirm that stated above by Oliveira (2002), regarding the fact that the intervention with parents in these cases requires greater intensity and frequency. Quagliatto et al. (2008), in the same way, point out that with patients in early infancy or faced with symptoms of autism, childhood psychosis or frameworks related to this, the relevance of the intensive work with parents is also justified in that ". . . there is a unit that still cannot be independent" (p. 47), having therefore a greater linkage of the psyche of the child to the parental unconscious. Greater independence of the child, in addition, also allows the focus to be more on his own issues during the therapeutic process, as pointed out by Oliveira (2002).

\section{Final Considerations}

The majority of the works taken for analysis emphatically dealt with the need for a thorough look at and careful work with the feelings and influences of the parents in the psychoanalysis of the child. The child remaining in the treatment, the preservation of the psychoanalytic setting, the resolution of the issues linked to the symptomatology and suffering of the child, and other factors which are associated with the viability and effectiveness of the treatment depend on questions related to the parents of the child and their relationship with the treatment. This theme seems to have received more attention and interests from authors in recent decades, as the comprehension has developed of the intimate relationship between the parental psyche and that of the child, still in formation.

The authors demonstrate this comprehension through the way of conceiving the constitution of the subject, so that the analysis constructed here markedly expresses ideas pertaining to the theory bequeathed by Lacan. According to the statements found here, the emphasis on the dependence of the psyche of the child on the parental phantasm puts the parents in a prominent position in the treatment.

Conversely, the importance is cited of the report of Freud (1909/1996) on the analysis of a 5 year old phobic boy, a process in which the father's participation had special repercussions. Regarding Klein's work, although it represents the pioneering analysis of children, only one article was found in which the basic theory was linked to this psychoanalytic line. Given the claim that the management of the issues addressed in this study depends on the theoretical framework adopted, the need remains to show how professionals working with the theoretical framework of Klein conduct their clinical work today, highlighting the relevance of further research on this issue, in particular. Similarly, it 
was noted that there were few works available online that deal with this issue according to Winnicott's understanding. This author also stands out in the context of this theme, when proposing ways of caring for the parents who seek to welcome the anguish and the exercise of the continent function, opening space for emerging demands that do not fit in the model of work of a traditional analysis.

The limitations of the present work should be highlighted, which include, the use of articles as the reference, from a systematic review of the literature at a given moment, found in only the three databases chosen and that were available online. Further work on the subject proposed here, with the use of more comprehensive reviews, would be relevant and enriching for its study.

The attitudes that the psychotherapist valorizes depend on a lot of factors that are present in the here now of the situation, the requirement brought by the family, the quantum of anguishes that the parents can support and the capacity of the environment to change to accommodate the therapeutic process of this child.

When dealing with the parents in the psychoanalytic treatment of the child, however, the therapist must be very clear about what he intends when proceeding in the care together with the parents, avoiding acting out, and taking care not to lose sight of the issue that is the child, primarily, the suffering patient with whom the therapist is concerned, although it is necessary to open spaces for the entry of other discourses and to welcome the family anguishes.

\section{References}

Aberastury, A. (1982a). Entrevistas posteriores com os pais. In A. Aberastury, Psicanálise da criança - Teoria e técnica (pp. 135-147). Porto Alegre, RS: Artes Médicas.

Aberastury, A. (1982b). A entrevista inicial com os pais. In A. Aberastury, Psicanálise da criançaTeoria e técnica (pp. 81-96). Porto Alegre, RS: Artes Médicas.

Andrade, M. L., Mishima-Gomes, F. K. T., \& Barbieri, V. (2012). Vínculos familiares e atendimento psicológico: A escuta dos pais sobre a alta da criança. Revista da SPAGESP, 13(1), 5-13. Retrieved from http://pepsic.bvsalud.org/pdf/ rspagesp/v13n1/v13n1a02.pdf

Bleichmar, S. (1994). Do discurso parental à especificidade sintomática na psicanálise de crianças. In A. M. S. Rosemberg (Ed.), O lugar dos pais na psicanálise de crianças (pp. 121-155). São Paulo, SP: Escuta.

Cabral, S. A., \& Levandowski, D. C. (2011). Representações maternas: Aspectos teóricos e possibilidades de avaliação e intervenção clínica. Estilos da Clínica, 16(1), 186-203. Retrieved from http://pepsic.bvsalud.org/pdf/estic/v16n1/ a11v16n1.pdf

Camarotti, M. C. (2010). O nascimento da psicanálise de criança - Uma história para contar. Reverso, 32(60), 49-54. Retrieved from http://pepsic. bvsalud.org/pdf/reverso/v32n60/v32n60a07.pdf

Checchinato, D. (2002). Psicanálise dos pais. Pulsional Revista de Psicanálise, 42-69. Retrieved from http://www.acpsicanalise.org.br/docs/psicanalise-dos-pais.pdf

Deakin, E. K., \& Nunes, M. L. T. (2009). Abandono de psicoterapia com crianças. Revista de Psiquiatria do Rio Grande do Sul, 31(3), 145151. Retrieved from http://www.scielo.br/pdf/ rprs/v31n3/a03v31n3

Ferrari, A. G. (2012). Sintoma da criança, atualização do processo constitutivo parental? Tempo Psicanalítico, 44(2), 299-319. Retrieved from http://pepsic.bvsalud.org/pdf/tpsi/v44n2/ v44n2a04.pdf

Ferro, A. (1995). A técnica na psicanálise infantil: A criança e o analista da relação ao campo emocional. Rio de janeiro, RJ: Imago.

Freud, S. (1996). Análise de uma fobia em um menino de cinco anos. In J. Salomão (Ed.), Edição standard brasileira das obras psicológicas completas de Sigmund Freud: Vol. 10 (pp. 33141). Rio de Janeiro, RJ: Imago. (Original work published in 1909)

Gastaud, M. B., Basso, F., Soares, J. P. G., Eizirik, C. L., \& Nunes, M. L.T. (2011). Preditores de não aderência ao tratamento na psicoterapia psicanalítica de crianças. Revista de Psiquiatria do Rio Grande do Sul, 33(2) 109-115. Retrieved from http://www.scielo.br/pdf/rprs/v33n2/1328. pdf

Klein, M. (1997). A técnica de análise no período de latência (A. Cardoso, Trans.). In J. Salomão 
(Rev. Ed.) \& E. M. R. Barros (Ed.), A psicanálise de crianças (pp. 78-98). Rio de Janeiro, RJ: Imago.

Klinger, E. F., Reis, B. K., \& Souza, A. P. R. (2011). A inclusão dos pais na clínica das psicoses infantis. Estilos da Clínica, 16(1). 96-115. Retrieved from http://www.revistas.usp.br/estic/ article/view/46109

Leone, C., \& Mariotto, R. M. M. (2007). Controvérsias no tratamento psicanalítico com crianças: Qual o lugar dos pais? Psicologia Argumentativa, 25(49), 135-142. Retrieved from http://www2.pucpr.br/reol/index.php/ PA?dd1 $=1654 \& d d 99=$ view

Lerner, R. (2002). A dimensão da enunciação no discurso da mãe acerca da criança psicótica. Estilos da Clínica, 4(13), 116-121. Retrieved from http://www.revistas.usp.br/estic/article/ view/61047

Lisondo, A. B. D. (2001). O lugar dos pais na análise de crianças e adolescentes: Uma menina-rainha em um trono-trincheira-prisão mental. Psyche, 5(8), 95-115. Retrieved from http://www.redalyc.org/pdf/307/30700807.pdf

Mannoni, M. (1987). A transferência em psicanálise de crianças. Problemas atuais. In $A$ criança, sua "doença" e os outros: O sintoma e a palavra (A. C. Villaça, Trans., $3^{\text {rd }}$ ed., pp. 67-101). Rio de Janeiro, RJ: Guanabara.

Martinez, A. L. M. (2014). Ressonâncias do inconsciente materno e familiar na sintomatologia infantil e no setting analítico à luz de um caso clínico. Estilos da Clínica, 19(1), 91-110. Retrieved from http://www.revistas.usp.br/estic/ article/view/81004

Melo, H. L. A., Andrade, F. C. B., \& Lima, H. M. C. (2012). Superando o falicismo: Sofrimento materno na psicanálise de crianças. Psicologia em Estudo, 17(3), 539-544. Recuperado em http:// www.scielo.br/pdf/pe/v17n3/a19v17n3.pdf

Nogueira, L. C. (2004). A pesquisa em psicanálise. Psicologia USP, 15(1-2), 83-106. Retrieved from http://www.scielo.br/pdf/pusp/v15n1-2/ a13v1512.pdf

Nunes, M. L. T., Silvares, E. F., Marturano, E. M., \& Oliveira, M. S. (2009, July/September). Crianças em risco: Abandono de psicoterapia. Psico, 40(3), 359-365. Retrieved from http://revistaseletronicas.pucrs.br/ojs/index.php/revistapsico/ article/view/6600/4827
Oliveira, I. T. (2002). Critérios de indicação para psicoterapia breve de crianças e pais. Psicologia: Teoria e Prática, 4(1), 39-48. Retrieved from http://editorarevistas.mackenzie.br/index.php/ ptp/article/view/1076

Petriciani, M. (2011). Uma relação tão delicada. Jornal de Psicanálise, 44(80), 149-163. Retrieved from http://pepsic.bvsalud.org/scielo.php?script $=$ sci arttext\&pid=S0103-58352011000100013

Priszkulnik, L. (1995). A criança e a psicanálise: O "lugar" dos pais no atendimento infantil. Psicologia USP, 6(2), 95-102. Retrieved from http://www.revistas.usp.br/psicousp/article/ view/34523

Quagliatto, H. S. M., Cunha, M. F., Chaves, L. S., Pajola, L. G., \& Lemgruber, K. (2008). Evoluções e revoluções na clínica psicanalítica infantil: Da orientação aos pais à avaliação-intervenção conjunta pais-filhos. Contextos Clínicos, 1(1), 4348. Retrieved from http://revistas.unisinos.br/ index.php/contextosclinicos/article/view/5477

Rosemberg, A. M. S. (1994). A constituição do sujeito e o lugar dos pais na análise de crianças. In A. M. S. Rosemberg (Ed.), O lugar dos pais na psicanálise de crianças (pp. 21-59). São Paulo, SP: Escuta.

Sei, M. B., Souza, C. G. P., \& Arruda, S. L. S. (2008). O sintoma da criança e a dinâmica familiar: Orientação de pais na psicoterapia infantil. Vínculo - Revista do NESME, 2(5), 101-219. Retrieved from http://pepsic.bvsalud.org/scielo.php? pid $=$ S $1806-$ $24902008000200009 \&$ script $=$ sci_abstract

Serralha, C. (2009). Winnicott com Gabrielle e seus pais. Natureza Humana, 11(1), 149-164. Retrieved from http://pepsic.bvsalud.org/ scielo.php?script $=$ sci_arttext\&pid $=$ S 1517 24302009000100007\&lng=pt\&nrm=i\&tlng=pt

Soler, V. T., \& Bernardino, L. M. F. (2012). A prática psicanalítica de Françoise Dolto a partir de seus casos clínicos. Estilos da Clínica, 17(2), 9-54. Retrieved from http://www.revistas.usp.br/estic/ article/view/49646

Sours, J. A. (1996). A aplicação de princípios da análise de crianças a formas de psicoterapia infantil. In J. Glenn (Ed.), Psicanálise e psicoterapia de crianças. Porto Alegre, RS: Artes Médicas.

Souza,A.S.L.(2012). Existeumlugarpara os pais reais: Reflexões sobre o lugar dos pais e do analista real 
na psicanálise de orientação kleiniana. Estilos da Clínica, 17(2), 278-289. Retrieved from http:// pepsic.bvsalud.org/scielo.php?pid=S1415$71282012000200007 \&$ script $=$ sci_arttext

Whitaker, C. (2003). O sintoma da criança como efeito do gozo materno: Entrevistas preliminares. Estilos da Clínica, 8(15), 124-139. Retrieved from http://pepsic.bvsalud.org/pdf/estic/v8n15/ v8n15a10.pdf

Winnicott, D. W. (1980). Fatores de integração e ruptura na vida familiar. In D. W. Winnicott, A familia e o desenvolvimento individual. Belo Horizonte, MG: Interlivros. (Original work published in 1961)
Winnicott, D. W. (1990). Provisão para a criança na saúde e na crise. In D. W. Winnicott, $O$ ambiente e os processos de maturação $\left(3^{\text {rd }} \mathrm{ed}\right.$., pp. 6269). Porto Alegre, RS: Artes Médicas. (Original work published in 1962)
Recebido: 19/02/2015

$1^{a}$ revisão: $25 / 1 / 2016$

$2^{a}$ revisão: $15 / 02 / 2016$

Aceite final: 21/02/2016 